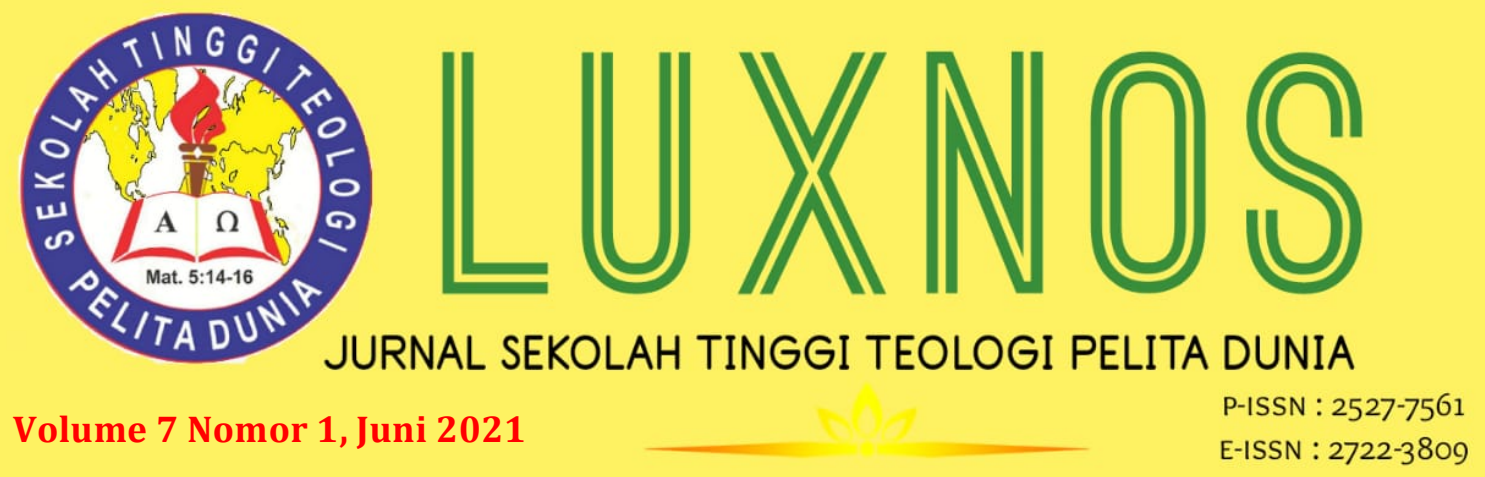

\title{
Kajian Teologis Terhadap Tindakan Bunuh Diri
}

\author{
Dapot Nainggolan \\ Sekolah Tinggi Teologi Pelita Dunia Tangerang \\ dapotnainggolan81@gmail.com
}

\begin{abstract}
This research is a theological study of suicide. With the aim, through this research, it can complement the congregational theological knowledge regarding suicide and build the congregation's faith in Jesus Christ. This research was conducted based on the author's observation that there are still many people who think that the cause of suicide is solely due to a person's mental weakness in understanding and accepting a life problem, so that in the form of such weakness he considers the sin of suicide will not affect the safety of the perpetrator. Based on this, then by using a qualitative approach and focusing on data or information from the Bible as the main source and the existing literature, it is found that the main cause of suicide is not merely a mental problem but is rooted in a false (wrong) faith. owned by the perpetrator and eventually develops into immoral behavior and ends with suicide. So that someone who commits suicide will not be saved not solely because of his suicide, but does not have the correct faith based on God's word.
\end{abstract}

Keywords: Theological Study, Suicide

\begin{abstract}
Abstrak: Penelitian ini merupakan sebuah kajian teologis terhadap tindakan bunuh diri. Dengan tujuan, melalui penelitian ini dapat memeperlengkapi pengetahuan teologi jemaat berkenaan dengan tindakan bunuh diri serta membangun iman jemaat kepada Yesus Kristus. Penelitian ini dilakukan berdasarkan pengamatan penulis bahwa masih banyak umat yang berpandangan, bahwa penyebab tindakan bunuh diri semata-mata karena kelemahan mental seseorang dalam memahami dan menerima suatu persoalan hidup, sehingga dalam bentuk kelemahan seperti itu menganggap dosa bunuh diri tidak akan mempengaruhi keselamatan si pelaku. Berdasarkan hal itu, maka dengan menggunakan pendekatan kualitatif dan menitik beratkan pada data atau informasi dari Alkitab sebagai sumber utama dan literaturliteratur yang ada diperoleh bahwa penyebab utama tindakan bunuh diri bukan semata-mata persoalan mental namun berakar pada iman yang palsu (salah) yang dimilik oleh sipelaku, dan akhirnya berkembang pada perilaku-perilaku amoral serta diakhiri dengan tindakan bunuh diri. Sehingga seseorang yang melakukan bunuh diri tidak akan selamat bukan semata-mata karena tindakan bunuh dirinya, melainkan tidak memiliki iman yang benar berdasarkan firman Tuhan.
\end{abstract}

Kata Kunci: Kajian Teologis, Bunuh Diri. 


\section{Pendahuluan}

Peristiwa bunuh diri masih terjadi hingga sekarang ini. Menurut WHO (World Health Organization) memperkirakan setiap tahun lebih dari 800 ribu orang meninggal akibat tindakan bunuh diri. Tindakan bunuh diri menjadi penyebab kematian tertinggi kedua pada rentang usia 15 sampai dengan 29 tahun. ${ }^{1}$ Indonesia sendiri menurut penelitian pada tahun 2010 tergolong tinggi untuk kasus tindakan bunuh diri. Hampir 50 ribu orang dari 220 juta penduduk meninggal tiap tahunnya dengan cara bunuh diri. ${ }^{2}$ Persentase angka itu bisa saja sudah bertambah pada tahun ini.

Dalam Alkitab dikisahkan bahwa ada beberapa orang yang melakukan tindakan bunuh diri, antara lain:

1. Raja Zimri yakni mati dengan cara membakar diri di istana raja dimana ia sendri berada di dalam istana tersebut (1 Raj. 16:18). Zimri menjadi seorang raja karena kudeta yang ia lakukan terhadap raja Ela anak Baesa. Dengan membunuh Ela, maka Zimri menggantikannya menjadi raja Yehuda (1 Raj. 16:8-13).

2. Raja Abimelekh mati oleh menghunus pedang dari bujangnya atas perintah Abimelek sendiri dengan berkata; "Hunuslah pedangmu dan bunuhlah aku, supaya jangan orang berkata tentang aku: Seorang perempuan membunuh aku". (Hak. 9:54). Abimelekh adalah anak Yerubaal dari gundiknya orang Sikhem (Hak. 8:31). Abimelekh menjadi raja dengan cara yang keji yakni dengan membunuh 70 orang saudaranya anak Yerubaal, sehingga ia menjadi raja (Hak. 9:5-6).

3. Raja Saul mati pada waktu melakukan peperangan melawan bangsa Filistin. Pada saat-saat kegentingan dalam peperangan tersebut, yang mana pasukanpasukannya telah banyak yang terbunuh bahkan anak-anaknya seperti Yonatan, Abinadab, dan Malkisua juga telah mati terbunuh oleh tentara-tentara Filisitn, sementara ia sendiri telah terluka parah akibat peperangan itu, maka raja Saul merasa bahwa saat itu adalah akhir dari semua kehidupannya, lalu ia mengambil pedang dari ajudannya (pembawa senjatanya) dan menghunus dirinya sendiri (1 Sam. 31:4).

4. Pengawal Saul juga mati dengan cara sengaja menjatuhkan dirinya ke atas pedangnya (1 Sam. 31:5). Ketika itu, pengawal Saul melihat bahwa rajanya telah mati, ia pun ikut bunuh diri dan mati bersama-sama dengan Saul pada hari itu juga.

5. Ahitofel adalah seorang penasihat raja Absalom anak Daud (2 Sam. 16:20). Pada suatu waktu ketika Absalom berencana untuk membunuh ayahnya Daud dan seluruh pasukannya, maka Absalom meminta nasihat dari Ahitofel dan Husai.

\footnotetext{
${ }^{1}$ https://www.intothelightid.org/tentang-bunuh-diri/apa-itu-bunuh-diri-yang-orang-sering-tanyakantentang-bunuh-diri/. Diakses pada 25 September 2020, pukul 10.00 WIB.

2 Santoso dkk., Bunuh Diri Dan Depresi Dalam Perspektif Pekerjaan Sosial (Prosiding Penelitian Dan Pengabdian Kepada Masyarakat 4.3, 2018), 390-398.
} 
Dari kedua penasihatnya itu, Absalom lebih memilih untuk melakukan nasihat Husai ketimbang nasihat dari Ahitofel. Melihat nasihatnya diabaikan oleh Absalom, maka Ahitofel merasa kecewa lalu menggantung dirinya sendiri dan mati (2 Sam. 17:23).

6. Simson adalah anak dari Manoah seorang yang berasal dari suku Dan. Simson adalah seorang nazir Allah (Hak. 13:7). Ia memerintah sebagai Hakim atas orang Israel selama 20 tahun (Hak. 16:31). Kekuatan yang diberikan oleh Allah kepadanya menjadikan dia mampu membunuh banyak tentara Filistin. Suatu ketika oleh karena bujuk rayu dari istrinya yang bernama Delila, akhirnya ia menceritakan rahasia kekuatannya yang berada pada "rambutnya". Maka istrinya berlaku jahat sehingga memotong rambut Simson, akhirnya Simson pun menjadi lemah. Dalam kondisi kelemahannya, Simson ditangkap oleh bangsa Filisitn lalu dibutakan kedua matanya kemudian dimasukkan ke dalam penjara. Setelah sekian lama terbelenggu dalam penjara, pada saat tertentu rambutnya mulai tumbuh, dan disaat itu pula Simson dibawa kesuatu gedung dimana rajaraja Filistin bersama masyarakat sedang mengadakan pesta-pora. Simson diikatkan dengan rantai pada tiang-tiang gedung tempat orang Filistin berpesta tersebut (Hak. 16). Lalu berserulah Simson kepada TUHAN, katanya; "Ya Tuhan ALLAH, ingatlah kiranya kepadaku dan buatlah aku kuat, sekali ini saja, ya Allah, supaya dengan satu pembalasan juga kubalaskan kedua mataku itu kepada orang Filistin" (ay.28). Kemudian Simson merobohkan seluruh gedung itu, dan seluruh orang Filistin yang berada disana mati. Namun Simson sendiri juga ikut mati pada peristiwa itu. Kisah kematian Simson ini telah menjadi kontroversial bagi berbagai kalangan. Ada yang berpendapat bahwa kematian Simson bukanlah akibat dari tindakan bunuh diri, melainkan akibat dari sebuah usaha yang dilakukan untuk melawan musuh dalam sebuah peperangan yang mana umum terjadi pada masa - masa Perjanjian Lama. Ia berperang melawan musuh dengan caranya, yang siap berkorban nyawa menjadi hal yang sangat patriotik dalam sebuah peperangan. Akan tetapi dilain pihak ada yang berpendapat bahwa tindakan Simson adalah tindakan bunuh diri merujuk pada ayat 30 bahwa ia dengan sadar mengetahuia tindakannya akan membunuh dirinya sendiri.

7. Yudas yang melakukan tindakan bunuh diri. Yudas adalah orang yang sebelumnya telah dipilih Yesus menjadi murid-Nya, namun ia telah melakukan dosa dan berkhianat dengan menjual Yesus kepada imam dan tua-tua bangsa Yahudi. Melihat Yesus telah dijatuhi hukuman mati, menyesallah dia, kemudian ia menggantungkan diri (Mat. 27:1-5).

Dengan peristiwa bunuh diri yang masih terjadi hingga sekarang, maka dirasa perlu untuk memberikan suatu kajian-kajian teologis berkenaan dengan tindakan 
bunuh diri tersebut. Meneliti untuk menemukan pandangan yang tepat dan benar berdasarkan penyataan kebenaran firman Tuhan. Sehingga dengan adanya penelitiaan ini dapat memberikan pendidikan teologi yang benar bagi orang percaya untuk lebih menghargai hidup sebagai persembahan demi memuliakan Tuhan.

\section{Metode Penelitian}

Pada penelitian ini penulis menggunakan metode kualitatif, khususnya pendekatan firman Tuhan dan literatur-literatur untuk memperoleh sebuah konsep dan pemahaman teologi yang benar berkenaan dengan penyebab dan dampak dari tindakan bunuh diri.

\section{Hasil dan Pembahasan}

Bunuh diri merupakan penyangkalan terhadap kedaulatan Allah

Menurut Kamus Besar Bahasa Indonesia definisi bunuh diri adalah dengan sengaja mematikan diri sendiri. ${ }^{3}$ Diberbagai laman internet dan pustaka-pustaka hampir senada memberikan definisi terhadap tindakan bunuh diri, yakni; sebuah tindakan yang dengan sadar dan dengan sengaja melakukan pembunuhan terhdap dirinya sendiri. ${ }^{4}$ Artinya bahwa upaya pembunuhan itu adalah atas kemauan yang terbunuh, dimana pelaku pembunuhan itu adalah orang yang terbunuh itu sendiri. Sehingga bunuh diri adalah prakarsa perbuatan yang mengarah pada kematian pemrakarsa. Bunuh diri merupakan sebuah tindakan sadar dari seseorang menggunakan kehendak bebasnya untuk mengakhiri (mematikan) kehidupannya dari dunia ini.

Alkitab baik Perjanjian Lama maupun Perjanjian Baru tidak secara spesifik memberikan ulasan mengenai tindakan bunuh diri kecuali hanya dalam titah keenam dalam kitab Taurat yang berbunyui: “Jangan membunuh" (lih. Kel. 20:13, Ul. 5:17). Akan tetapi, melihat hakikat tindakan bunuh diri tersebut adalah sebuah upaya sadar dan sengaja untuk mematikan (membunuh) diri sendiri, maka apabila dikaji dari perspektif firman Tuhan sungguh telah melanggar dan bahkan telah menyangkal otoritas Allah atas kepemilikan seluruh eksistensi kehidupan manusia. Orang yang melakukan tindakan bunuh diri secara tegas telah menjadikan diri sebagai Tuan atas dirinya sendiri.

\footnotetext{
3 "Kamus Besar Bahasa Indonesia (KBBI), Versi Online", https://kbbi.web.id/bunuh. Diakses pada 25 September 2020, pukul 10.00 WIB.

${ }^{4}$ http://eprints.mercubuana-yogya.ac.id/942/3/5.\%20BAB\%20II.pdf

http://etheses.uinmalang.ac.id/806/6/10410163\%20Bab\%202.pdf.

http://repository.usu.ac.id/bitstream/handle/123456789/18244/Chapter\%20II.pdf;jsessionid=823E174616E5C 72CE87ED375D46FEB9D?sequence=4". Diakses pada tanggal 25 September 2020, pukul 11 WIB.
} 
Dari beberapa konteks bagian firman Tuhan dapat melegitimasi tindakan bunuh diri tersebut sebagai sebuah tindakan penyangkalan akan kedaulatan Allah, antara lain:

Pertama: Kejadian 2:7 berbunyi: "ketika itulah Tuhan Allah membentuk manusia itu dari debu tanah dan menghembuskan nafas hidup ke dalam hidungnya; demikianlah manusia itu menjadi makhluk yang hidup." Kemudian dalam Nehemia 9:6 berkata: "Hanya Engkau adalah Tuhan! Engkau telah menjadikan langit, ya langit segala langit dengan segala bala tentaranya, dan bumi dengan segala yang ada di atasnya, dan laut dengan segala yang ada di dalamnya. Engkau memberi hidup kepada semuanya itu dan bala tentara langit sujud menyembah kepada-Mu." Dalam Ayub 12:10 berbunyi demikian: "bahwa di dalam tangan-Nya terletak nyawa segala yang hidup dan nafas setiap manusia?". Berdasarkan bagian-bagian firman Tuhan ini menyatakan bahwa hidup merupakan pemberian Allah, maka Allah yang berhak mengambil kepunyaanNya. Oleh karena hidup adalah pemberian Tuhan, maka manusia juga tidak boleh menolaknya dengan cara melakukan bunuh diri. Hal yang sama juga diutarakan oleh Verkuyl sebagaimana dikutip oleh Josep Gracia Febi dalam artikelnya yang berjudul Bunuh Diri Ditinjau Dari Iman Kristen, berkata demikain:

"Dan Tuhan melarang kita menolak hidup kita sendiri, artinya membunuh diri, sebab hidup dan mati bukan terletak dalam tangan kita, melainkan dalam Tangan Tuhan. Tetapi pada manusia itu Tuhan telah meletakkan tanggung jawab atas hidupnya sendiri. Manusia mempunyai kebebasan mengenai hidupnya sendiri, tetapi kebebasan itu disertai suatu tanggung jawab. Ia bertanggung jawab kepada Tuhan atas segala apa yang diperbuatnya terhadap hidupnya. Manusia dapat menerima karunia yang disebut hidup itu, tetapi iapun dapat menolaknya, hal mana merupakan suatu perbuatan yang amat mengerikan, sebab menolak hidup berarti membunuh diri". ${ }^{5}$

Kedua: Ulangan 32:39 berbunyi: "Lihatlah sekarang, bahwa Aku, Akulah Dia. Tidak ada Allah kecuali Aku. Akulah yang mematikan dan yang menghidupkan, Aku telah meremukkan, tetapi Akulah yang menyembuhkan, dan seorangpun tidak ada yang dapat melepaskan dari tangan-Ku". 1 Samuel 2:6; "Tuhan mematikan dan menghidupkan, Ia menurunkan ke dalam dunia orang mati dan mengangkat dari sana". Kemudaian dalam Pengkhotbah 8:8a berkata: "Tiada seorangpun berkuasa menahan angin dan tiada seorangpun berkuasa atas hari kematian." Dari bagian-bagian firman Tuhan ini sudah sangat jelas bahwa Allah yang berdaulat atas hidup dan mati manusia. Allah yang mencipatakan manusia dan Dialah yang berhak untuk mengambilnya pula. Manusia tidak boleh bertindak mengambil posisi Allah untuk melakukan otoritas Allah. Sebab

\footnotetext{
5 Josephine Gracia Febi, Bunuh Diri Ditinjau Dari Iman Kristen", https://tobiong.wordpress.com/2009/08/08/21/\#_ftn65. Diakses 25 September 2020, pukul 15:10 WIB.
} 
jika hal itu terjadi, manusia telah menjadikan dirinya Tuan atas dirinya sendiri. Hal ini adalah menyangkali eksistensi Allah.

Ketiga: Keluaran 20:13 berbunyi; “Jangan membunuh". Ulangan 5:17; "Jangan membunuh". Berdasarkan Keluaran 20:13 dan Ulangan 5:17 ini telah mensahkan bahwa tindakan bunuh diri adalah tindakan menolak untuk taat kepada Titah Tuhan Allah. Sebagai manusia yang diciptakan oleh Allah, segambar dan serupa dengan-Nya, maka manusia itu adalah ciptaan yang sangat berharga di mata-Nya. Manusia yang diciptakan Allah menurut gambar dan rupa-Nya juga menyatakan bahwa manusia adalah wakil Allah di mana terpancar karakter dan sifat Allah di dalamnya. Oleh karena itu, ketika seseorang membunuh gambar Allah, maka dia telah melakukan 'kekerasan' terhadap Tuhan sendiri.

Keempat: 1 Korintus 6:19-20 berbunyi; “Atau tidak tahukah kamu, bahwa tubuhmu adalah bait Roh Kudus yang diam di dalam kamu, Roh Kudus yang kamu peroleh dari Allah, dan bahwa kamu bukan milik kamu sendiri? Sebab kamu telah dibel dan harganya telah lunas dibayar: Karena itu muliakanlah Allah dengan tubuhmu!" Sebagai seorang yang percaya, tubuh bukan sekedar persoalan fisik, melainkan menjadi tempat Allah bersemayam. Manusia telah ditebus dari ikatan dosa sehingga kini telah menjadi milik Tuhan. Otoritas tertinggi terhadap tubuh berada pada kedaulatan kehendak Allah. Tubuh bukan lagi untuk mengerjakan kenikmatan duniawi atau sebaliknya, hanya ingin merasakan sakitnya penderitaan. Melainkan melalui semua peristiwa suka dan duka, manusia harus menggarapnya untuk mempermuliakan Tuhan.

Dari semua bagian-bagian firman Tuhan yang telah dikemukan di atas jelas menyatakan bahwa tindakan bunuh diri merupakan tindakan yang sangat ditentang oleh Allah. Secara sengaja dan sadar, serta tanpa dorongan dari pihak manapun pada titik tertentu seseorang telah menjadikan dirinya Tuan atas dirinya dan melakukan tindakan mematikan dirinya. Jelas jenis dosa sperti ini adalah dosa penyangkalan akan kedaulatan Allah. Kedaulatan Allah di dalam Alkitab disajikan dalam bentuk semacam antinomi. Antinomi adalah dua kebenaran yang tampaknya tidak berkesesuaian. Antinomi muncul ketika ada dua kebenaran yang keduanya tak dapat disangkal tetapi tampak tak dapat didamaikan. ${ }^{6}$ Antinomi yang dimaksud disini adalah apa yang tampaknya berkontradiksi antara kedaulatan Ilahi dan tanggung jawab manusia. Dengan kata lain bahwa ada yang Allah lakukan sebagai Raja dan ada yang Allah lakukan sebagai Hakim. Allah sebagai Raja mengatur dan mengendalikan segala sesuatu, termasuk tindakan manusia sesuai dengan maksud-maksud-Nya. Namun sebagai Hakim, Dia menuntut setiap manusia bertanggung jawab atas semua pilihan dan

\footnotetext{
${ }^{6}$ J.J. Parker, Penginjilan dan Kedaulatan Allah (Surabaya: Momentum, 2003), 9.
} 
segala perbuatannya (bdk. Kej. 45:8, Kej. 50:20, Ams. 16:9, Mat. 10:29, dan Mat. 25, Rom. 2:1-6)7.

Seseorang yang telah mendengar Injil bertanggung jawab atas respon yang mereka berikan terhadap kabar Injil tersebut. Jika mereka menolak berita Injil tersebut maka mereka akan mendapatkan maut (lihat Yoh. 3:18). Bagi pikiran manusia hal seperti antinomi memang sulit. Hal itu pula dikemukakan oleh Paulus dalam kitab Roma 9:19: "Jika demikian, apa lagi yang masih disalahkan-Nya? Sebab siapa yang menentang kehendak-Nya?". Allah adalah Raja yang berdaulat mengatur dan menentukan setiap perbuatan manusia, bagaimana mungkin Ia bisa bertindak sebagai Hakim dan menghukum berbagai pelanggaran yang diperbuat manusia? Namun Paulus menegasakan pada ayat selanjutnya bahwa Allah tidak bertindak seperti yang dipikirkan oleh manusia. Justru Palus mencela orang yang bertanya demikian: "Siapakah kamu, hai manusia, maka kamu membantah Allah? (ayat 20)". Oleh karena itu, tindakan orang yang melakukan bunuh diri telah menuntut pertanggungjawaban sebagai sebuah tindakan penyangkalan akan kedaulatan Allah.

\section{Metode bunuh diri}

Ada beberapa metode atau cara yang digunakan oleh orang-orang untuk melakukan bunuh diri antara lain:

- Dengan cara mengikat tali pada leher lalu menggantungkan diri,

- Makan atau minum racun,

- Menembak diri sendiri dengan senjata api,

- Menenggalamkan dirisendiri ke dalam air,

- Melompat dari tempat-tempat yang tinggi,

- Menusuk dirinya dengan benda-benda tajam, dan

- Menabrakkan dirinya pada kereta api yang sedang melintas.

\section{Faktor penyebab bunuh diri}

Tidak mudah untuk mendeteksi perilaku atau gejala-gejala dari seseorang dalam proses-proses menuju tindakan melakukan bunuh diri. Jarang sekali dijumpai penyebab-penyebab tunggal dari seseorang yang melakukan tindakan bunuh diri tersebut. Selalu berbeda-beda berdasarkan zaman dan konteks situasi yang dihadapi oleh pelaku. Sehingga hal ini juga menjadi faktor utama yang menimbulkan kesulitan untuk melakukan tindakan-tindakan pencegahan terhadap niat seseorang untuk melakukan bunuh diri. Dari beberapa orang yang melakukan tindakan bunuh diri yang dikisahkan dalam Alkitab juga tidak ada alasan yang seragam. Beberapa artikel jurnal menyebutkan bahwa faktor penyebab seseorang melakukan bunuh diri adalah karena

7 Ibid., 12-13. 
adanya kerusakan mental atau depresi. Depresi yang berat menjadi salah satu penyebab terjadinya bunuh diri. Depresi timbul karena konsep diri yang keliru sehingga membuat mereka merasa tidak diinginkan, tidak berharga dan tidak seorang pun mengasihi mereka. ${ }^{8}$ Depresi adalah suatu pengalaman yang menyakitkan, mood yang terganggu, perasaan tidak memiliki harapan lagi, dan kondisi demikian terjadi secara berkepanjangan yang mewarnai seluruh proses mental (berpikir, berperasaan dan berperilaku) seseorang. Dari perasaan-perasaan negatif tersebutlah bisa timbul pikiranpikiran yang bisa membahayakan; dan bunuh diri adalah salah satu dampaknya. ${ }^{9}$ Merasa tidak memiliki solusi terhadap masalah yang sedang menimpanya maka tindakan bunuh diri dipandangnya sebagai jalan terbaik untuk menghindari kepedihan yang berlebihan.

Satu hal yang tidak bisa dilupakan yang justru sebagai faktor utama dari seseorang yang melakukan bunuh diri adalah faktor iman. Faktor iman yang dimaksud adalah bukan semata-mata masalah kemampuan seseorang dalam mengaku percaya, melainkan iman yang lahir dari Roh Kristus dan dituntun oleh Roh yang sama untuk bersatu dengan tubuh Kristus. Kesatuan hidup dengan tubuh Kristus yang menjadikan orang percaya menegakkan kehendak bebesnya untuk melakukan kebaikan dan tidak lagi budak dosa (band. 2 Kor. 5:17). Hal inilah yang sesungguhnya tidak ada pada seseorang yang melakukan bunuh diri. Karena keberadaannya diluar Kristus, maka ketika masalah datang ukuran-ukuran kebaikan atas persoalan untuk mengambil keputusan adalah dirinya sendiri bukan otoritas Kristus. Ego manusia batiniah pelaku bunuh diri yang terus yakin dan berjuang pada ukuran hukum dan perbuatanperbuatannya yang dianggapnya dapat meraih sorga, hal itulah yang merusak seuluruh tatanan kehidupan seseorang hingga pada kematiaanya. ${ }^{10}$ Tidak memiliki kesejatian iman sebagaimana layaknya seseorang yang telah lahir baru di dalam anugerah Yesus Kristus menjadi penyebab utama mengapa seseorang bunuh diri. Seseorang yang tidak dilahir barukan oleh kasih karunia Allah tidak mungkin memahami kehidupan secara benar (band. Yoh. 3:1-21).

Sejatinya; Semua manfaat keselamatan yang telah dianugerahkan Bapa kepada gereja sejak kekekalan dan yang diperoleh Anak di dalam waktu pada saat yang sama adalah Karunia Roh Kudus. Maka Kristus melalui Roh, dan Bapa sendiri melalui Kristus, memasukkan semua anak-Nya ke dalam persekutuan yang paling intim dengan diri-

\footnotetext{
${ }^{8}$ Mallo, Hermin, " Analisis Faktor Penyebab Utama Kecenderungan Bunuh Diri di Kalangan Remaja yang Berusia 15-17 Tahun di Makassar 8.1, Jurnal Jaffray (2010): 35-43.

${ }^{9}$ Chenia Ilma Kirana Santoso, Meilanny Budiarti, Dessy Hasanah Siti Asiah, "Bunuh Diri Dan Depresi Dalam Perspektif Pekerjaan Sosial", Penelitian Dan Pengabdian Kepada Masyarakat 4.3 (2018): 390-398.

${ }^{10}$ Herman Ridderbos, Paulus: Pemikiran Utama Theologinya, Terjemahan Hengky Ongkowidjojo (Surabaya: Momentum, 2008), 126-127.
} 
Nya. ${ }^{11}$ Roh Kudus memampukan orang-orang percaya untuk bertekun hingga akhir hidupnya akan diselamatkan. Panggilan berfungsi bukan hanya pada permulaannya untuk mengundang orang-orang yang tidak percaya kepada iman dan pertobatan, tetapi juga untuk menegur dan memperingatkan mereka, mengajar dan memimpin orang percaya secara permanen. ${ }^{12}$ Itulah sebabnya penulis tidak setuju dengan sebuah pandangan dari seorang penulis dalam sebuah jurnal yang mengatakan bahwa, di dalam proses pengudusan, orang yang sudah lahir baru tidak luput dari kecenderungan berbuat dosa, termasuk dosa bunuh diri. ${ }^{13}$ Benar adanya bahwa orang yang sudah lahir baru masih mungkin berdosa, namun demikian tidak ada satu ayat firman Tuhan yang mendukung bahwa seseorang yang telah lahir baru tatkala menghadapi suatu jenis penderitaan maka Tuhan akan memaklumi tindakan bunuh diri sebagai solusi. Justru sebaliknya Alkitab bersaksi bahwa; bukankah Stefanus mengalami pendertiaan yang begitu berat, Paulus mengalami penderitaan yang sangat keras, Ayub juga mengalami penderitaan yang begitu menyiksa, bahkan Sang Mesias sendiri dalam ke-ManusiaanNya mengalami kesejatian pendertiaan, namun demikian sungguh amat jelas Alkitab bersaksi bahwa, baik Stefanus, Paulus, Ayub, dan bahkan Yesus Kristus yang dalam keManusiaan-Nya tidak mengambil pilihan tindakan bunuh diri sebagai jalan menghindari penderitaan mereka, melainkan penyerahan diri pada kuasa dan kehendak Allah Bapa di Surga (band Mat. 26:42, Kis. 7:54-60, 2 Kor. 11: 23-28 Ayb. 42). Iman yang benar selalu membawa pada pengakuan yang benar akan Kedaulatan Allah. Tetapi iman yang palsu akan menjadikan seseorang untuk selalu terikat pada perbudakan dosa. Tindakan bunuh diri adalah tanda ultima dari kepalsuan iman seseorang (band. Tit. 1:15-16).

\section{Dampak tindakan bunuh diri}

Berdasarkan topik pembahasan dari tulisan ini tentang tindakan bunuh diri, mka muncul pertanyaan bahwa apakah seseorang yang telah melakukan tindakan bunuh diri memperoleh keselamatan kekal sorgawi? Berkenaan dengan jawaban atas pertanyaan ini umumnya timbul dua aliran pandangan. Pandangan yang pertama merujuk pada paham Armenian dan pandangan kedua merujuk pada konsep Calvinisme berkenaan dengan keselamatan.

Pandangan yang didasari oleh konsep Armenianisme akan cenderung menyatakan bahwa orang yang melakukan tindakan bunuh diri tidak akan diselamatkan oleh Tuhan. Kelompok ini berangkat dari paham bahwa semua orang mampu percaya atau memenuhi syarat-syarat untuk diselamatkan. Hal tersebut

\footnotetext{
${ }^{11}$ Herman Bavinck, Dogmatika Reformed, Jilid 3, Terjemahan Ichwe G. Indra dan Irwan Tjulianto (Surabaya: Momentum, 2016), 750.

12 Ibid,.

${ }^{13}$ Sylva Donna, Keselamatan dari Orang Kristen yang Bunuh Diri, (Jakarta: BPK Gunung Mulia, 2013), 57.
} 
disebabkan karena Allah memberikan anugerah yang datang terlebih dahulu (prevenient grace). Allah memberikan anugerah tersebut tanpa pandang bulu. Dengan anugerah tersebut seseorang mampu memberikan tanggapan yang benar terhadap Injil Kristus Yesus. Dengan demikian, keselamatan dapat diperoleh melalui usaha orang tersebut menerima tawaran Yesus untuk bertobat. Berdasarkan penjelasan di atas, pandangan ini menunjukkan adanya campur tangan manusia dalam proses keselamatan dirinya dan bukan seratus persen anugerah Allah. Dengan mengacu kepada Ibrani 6:46; 10:26-27, pandangan ini menyimpulkan bahwa ada kemungkinan orang yang sudah percaya akan murtad dan meninggalkan Yesus sehingga keselamatannya bisa hilang sebagaimana terjadi pada orang yang melakukan tindakan bunuh diri. ${ }^{14}$

Penulis memiliki perbedaan pandangan dengan kelompok yang menganut Armenianisme tentang keselamatan. Alkitab dengan tegas dan jelas menyatakan bahwa keselamatan tidak pernah dapat diperoleh oleh usaha manusia karena telah dirusak oleh dosa (Rom. 3:23). Dosa membuat manusia tidak bisa tidak berbuat dosa. Namun oleh ketetapan kasih karunia Allah melalaui Kristus di dalam pimpinan Roh Kudus telah memilih dan membenarkan orang berdosa menjadi layak dihadapan Allah (band. Rom. 3:24, Ef. 2:8-9, Yoh. 3:16). Itulah sebabnya pada uraian sebelumnya penulis kemukakan bahwa tindakan bunuh diri sesungguhnya bukanlah faktor penentu selamat atau tidaknya seseorang, melainkan bahwa tindakan itu hanyalah sebagai tanda akhir dari seorang pelaku yang memang adalah orang diluar tubuh Kristus. Dengan demikian bahwa, tanda itu menjadi tegas dan nyata bahwa pelaku bunuh diri bukan pewaris kerajaan Allah (band. Tit. 1:15-16).

Sementara pandangan yang kedua adalah kelompok yang memandang bahwa keselamatan tidak akan hilang sekalipun seseorang telah melakukan dosa bunuh diri. Kelompok yang memiliki pandangan ini merujuk pada teori keselamatan Yohanes Calvin. Calvinisme yang menekankan konsep kerusakan total dalam diri manusia ketika jatuh dalam dosa (total depravity), dengan kedaulatan Allah yang merupakan Sang Pencipta dan Tuhan atas segala sesuatu bebas untuk melakukan apa saja yang dikehendaki-Nya. Allah tidak tunduk dan bertanggung jawab pada pihak mana pun. Dengan demikian, keselamatan seseorang ditentukan oleh pilihan Allah dan sudah ditentukan sebelumnya (Ef. 1:4-5; Rm. 8:29; 9:16; Yoh. 15:16; Kel. 33:19).15 Dari konsep keselamatan sebagaimana di utarakan Calvin, maka beberapa kalangan menjadikan referensi untuk melegitimasi seseorang yang melakukan bunuh diri tetap diselamatkan oleh Allah. Dosa bunuh diri dipandang sebagai sebuah kelemahan manusia akibat

\footnotetext{
${ }^{14}$ R. C. Sproul, Kaum Pilihan Allah, (Terjemahan Rahmiati Tanudjaja) (Malang: Literatur SAAT, 1995),
} 116.

${ }^{15}$ Milliard J. Erickson, Teologi Kristen, (Vol. 3), (Malang: Gandum Mas, 2004), 112-114. 
tekanan-tekanan psikologis namun hal itu tidak akan menghilangkan keselamatannya. Kasih Allah memaklumi setiap kelemahan manusia ketika jatuh dalam dosa. ${ }^{16}$

Pada dasarnya penulis adalah seorang yang selama ini bahkan hingga kini lebih mengambil sikap untuk lebih banyak setuju pada pandangan-pandangan Calvinisme. Bahkan termasuk pada kajian keselamatan orang yang melakukan bunuh diri pada penelitian ini, sesunggunya penulis dalam beberapa hal juga merujuk pada teori Yohannes Calvin. Penulis sangat percaya bahwa pilihan Allah tidak mungkin dibatalkan oleh tindakan apapun dari manusia. Namun demikian pada konteks tindakan bunuh diri seseorang bukan semata-mata karena tindakan itu yang menghilangkan keselamatannya, melainkan pada hakikatnya bahwa pengakuan iman sebelum matinya pelaku bunuh diri adalah merupakan pengakuan iman yang palsu. Untuk menegaskan pandangan ini, penulis akan memberikan pertanyaan-pertanyaan untuk menghantar setiap pembaca bahwa sungguh tindakan bunuh diri adalah sebagai sebuah penyataan ultima dari kepalsuan iman seseorang yang melakukan bunuh diri;

1. Bagaimana menentukan ukuran berat-ringannya sebuah penderitaan yang dihadapai seseorang sehingga Allah pun harus memakluminya dan akirnya melegitimasi sebuah tindakan bunuh diri sebagai sebuah tindakan yang tidak akan mempengaruhi keselamatan kekal seseorang?

2. Apakah tindakan Allah untuk memaklumi kelemahan manusia itu sampai pada titik dimana seseorang dengan sengaja dan sadar atas resiko tindakan pembunuhan yang dilakukan, yakni; menghantar dirinya sendiri pada kematian dengan demikian telah sengaja dan sadar meniadakan ruang kesempatan untuk pertobatan?

3. Kalau demikian adanya bahwa sebuah penderitaan memperbolehkan kita untuk mengakihiri kehidupan di dunia ini, bukankah Surga itu sebuah kerinduan karena disana penuh nikmat tiada tara, mengapa setiap orang percaya tidak mempercepat waktunya menuju kesana dengan jalan bunuh diri? Bukankah pandangan seperti ini menjadi salah satu dasar bagi orang yang melakukan bunuh diri yakni untuk menghindari dunia yang penuh pendertiaannya? Gagasan ini sangatlah berbahaya dan sangat bertentangan dengan maksud kedaulatan Allah yang menghendaki setiap umat-Nya melalui seluruh eksistensi hidupnya menjadi penyataan kasih Allah bagi dunia! Kalaupun kematian jasmani harus nyata sebagai akibat dari dosa menuju penyataan kesempurnaan anugerah Allah adalah berdasrkan penetapan Allah bagi penyucian umat-Nya. ${ }^{17}$ Kata penetapan terhadap kematian orang percaya tentu sangat misteri dan tidak mungkin di tebak. Namun demikian sangat tegas bahwa orang yang membunuh dirinya

\footnotetext{
${ }^{16}$ Ibid.,...Donna, Sylva, 57.

${ }^{17}$ Louis Berkhof, Teologi Sistematika; Doktrin Akhir Zaman, Terjemahan Yudha Thianto (Surabaya: Momentum, 2008), 22.
} 
sendiri tidak mungkin atas penetapan Allah. Sebab tidak mungkin Allah menghendakai umat pilihan-Nya jadi pembunuh.

4. Mungkinkah seorang yang sudah dipilih Tuhan akan mengalami kelumpuhan logika sehingga tidak mampu lagi untuk mengandalkan imannya kepada Allah dalam bertahan melawan semua derita? Bukankah predestinasi dan providensia Allah bagaikan dua sisi mata uang yang tidak terpisahkan?

Penulis menyadari bahwa tidak mudah untuk menentukan jawaban-jawaban terhadap semua pertanyaan-pertanyaan diatas. Akan tetapi penulis akan berusaha memberikan jawaban-jawaban berdasarkan kacamata Alkitab berkenaan dengan tindakan bunuh diri tersebut. Bukan dalam rangka menghakimi akan iman dan keselamatan seseorang, melainkan untuk menyajikan sebuah perspektf. Alkitab jelas berbicara bahwa tidak ada usaha manusia untuk memperoleh Sorga, melainkan hanya oleh kasih karunia Allah (Ef. 2:8,9). Allah yang berdaulat memilih siapa yang dikehendaki-Nya untuk diselematakan. Namun demikian pemilihan Allah (predestinasi) terhadap manusia untuk menerima anugerah keselamatan akan di serta dengan pemeliharaan-Nya (providensi). Predestinasi dan provinedensia Allah terjadi supaya setiap orang diselamatakan dan keselamatan itu bertujuan untuk memuliakan Allah melalui seluruh eksistensi manusia baik di bumi maupun di surga, itulah kedaulatan Allah (band. Rom.11:36). Sehingga sekalipun masih memungkinan bagi orang percaya untuk melakukan dosa di dunia ini, namun karena kedaulatan Allah tidak mungkin tidak memberikan ruang untuk menyesali dan mengakui dosanya. Kesempatan pengakuan itu pasti diberi. Tujuannya bukan supaya diselamatkan kembali, melainkan peristiwa itu menjadi penyataan kasih Allah pada setiap orang percaya dan juga pada dunia. Penulis setuju bahwa keselamatan tidak akan pernah hilang dari seseorang yang telah dianugerahi oleh Kedaulatan Allah sebagaimana yang dianut oleh kalangan Calvinis. Namun demikian buah keselamatan itu harus selalu nyata dalam buah-buah kehidupannya dan terpancar hingga pada akhir pertandingannya di dunia ini tetap setia pada otoritas Allah. Kelemahan manusia karena masih hidup di dalam daging yang tidak sempurna dan juga karena masih berada dalam Dunia mungkin saja seseorang dapat jatuh ke dalam dosa, namun Alkitab berkata bahwa seseorang yang sungguh-sungguh ahli waris kerajaan Sorga, takkan jatuh sampai tergeletak, karena akan ditopang oleh tangan Tuhan (lih. Maz. 37:23-26).

Calvin dalam buku Institutio, mengelompokkan manusia pada empat golongan antara lain:

1. Karena tidak diperlengkapi dengan pengetahuan akan Allah, maka manusia terbenam dalam penyembahan berhala,

2. Memang diberi tahu mengenai rahasia-rahasia iman tetapi karena kehidupannya penuh kecemaran, dengan perbuatannya mengingkari Allah yang dia akui dengan bibir, dan hanya namanya saja orang Kristen, 
3. Adalah orang munafik yang menutupi kejahatan hatinya dengan berpura-pura baik;

4. Dilahirkan kembali oleh Roh Allah dan menjalani kesalehan hidup dengan benar. ${ }^{18}$

Maka lebih lanjut, Yohannes Calvin memberikan penjelasan terhadap golongangolongan manusia diatas merujuk pada pandangan Agustinus yang mengatakan;

"Semua orang yang terasing dari ibadah kepada Allah yang Esa, sekalipun dianggap pantas dikagumi karena harumnya kebajikan mereka (seperti golongan manusaia pertama), tidak layak mendapat imbalan, bahkan harus mendapat hukuman, oleh karena mereka mengotori pemberian - pemberian Allah yang suci dengan kecemaran hati mereka. Hal-hal yang benar senantiasa bertujuan supaya Allah dilayani: segala sesuatu diarahkan ketujuan lain, sudah sewajarnya kehilangan nama kebenaran. Dan karena mereka tidak memperhatikan tujuan yang ditetapkan oleh hikmat Allah, maka karya mereka, meskipun tampaknya dilaksanakan dengan baik, adalah dosa, sebab maksudnya jahat. Sebab, kesetiaan dalam melaksanakan kewajiban- kewajiban tidaklah diukur menurut perbuatan, tetapi menurut maksud yang di tentukan oleh kedaulatan Allah. Hal ini berlaku juga bagi golongan manusia yang kedua dan yang ketiga seperti yang disebut dalam pembagian di atas"19

Herman Bavinck dalam buku yang berjudul Dogmatika Reformed, Jilid 3, mengatakan; “ Didalam 1 Yohanes 5:16, kita kemabli mendapati kesaksian bahwa ada suatu dosa yang karena naturnya cenderung mambawa kepada kematian tanpa konversi (pertobatan) dan yang untuknya Yohanes tidak mengatakan, yaitu tidak memerintahkan, bahwa kita harus berdoa. Jika iman seseorang yang dipilih oleh Allah, tidak akan sampai melakukan dosa tanpa pertobatan." 20 Augustine di dalam menanggapi kasus bunuh diri yang dilakukan oleh para wanita yang telah diperkosa oleh para Barbarian yang menyerbu kota Roma, menyatakan bahwa manusia wajib memelihara harta milik Allah yang dipercayakan kepadanya. Tubuh dan jiwa kita adalah kepunyaan Allah dan orang yang bunuh diri berdosa terhadap Penciptanya. Bagi Augustine, bunuh diri bukan hanya pelanggaran langsung atas perintah keenam, "Jangan membunuh", melainkan suatu dosa yang tak terampuni yang merampas kesempatan pertobatan dan penyesalan. ${ }^{21}$

Berdasarkan uraian pembahasan di atas maka beberapa pokok yang menjadi hasil dari penelitian ini adalah sebagai berikut:

\footnotetext{
${ }^{18}$ Yohannes Calvin, Institutio, Terjemahan Winarsih dan J.S. Aritonang (Jakarta: BPK Gunung Mulia, 2009), 168-169.

${ }^{19}$ Ibid., 170.

20 Ibid., ...Herman Bavinck, 189.

21 Ibid., ...Josephine Gracia Febi, 33.
} 
1. Dari berbagai ayat firman Tuhan, seperti; Kejaidan 2:7, Nehemi 9:6, Ayub 12: 10, Ulangan 32:39, 1 Samuel 2:6, Pengkhotbah 8:8a, Keluaran 20:13, Ulangan 5:17, 1 Koritus 6:19-20, nyata dan jelas bahwa betapa tindakan bunuh diri adalah tindakan yang sangat ditentang oleh Allah. Dengan sengaja dan sadar tanpa dorongan dari pihak manapun pada titik tertentu manusia telah menjadikan dirinya Tuan atas dirinya dan melakukan tindakan bunuh diri. Jelas jenis dosa seperti ini adalah dosa penyangkalan akan otoritas dan kedaulatan Allah. Sehingga dosa tindakan bunuh diri adalah tanda-tanda ultima dari seorang pelaku pembunuhan bahwa sesungguhnya orang tersebut bukanlah golongan pewaris keselamatan kekal.

2. Bahwa orang yang melakukan bunuh diri bukanlah pilihan Allah. Sebab pemilihan Allah pasti sempurna karena di sertai dengan providensia-Nya sehingga menjadikan umat pilhan-Nya tidak akan menyangkali kedaulatan-Nya melalui tindakan bunuh diri.

3. Umat pilihan Allah masih mungkin berdosa, tetapi dosa yang dimaksud bukanlah jenis dosa bunuh diri yang membawa pada maut. Dengan providensia Allah bagi umat pilihan pasti memberikan ruang untuk pengakuan (pertobatan) tatkala jatuh dalam dosa (band. Maz. 37:23-26).

4. Ketika dosa seseorang telah membawanya pada kematiannya maka itu menjadi sebuah indikator bahwa orang itu tidak diperkenankan untuk menikmati pembaruan iman, dengan kata lain bahwa orang tersebut ditolak oleh Allah karena telah menyangkali otoritas Tuhan.

\section{Kesimpulan}

Sebagai umat pilihan Allah, orang percaya di panggil untuk menjadi saksi-saksi Allah. Menikmati-Nya bukan saja dalam peristiwa-peristiwa suka namun juga pada saat peristiwa duka. Peristiwa duka menghantarkan manusia untuk mengenang kesengsaraan Kristus dan sekaligus mendorong untuk tetap melekat dan bergantung terus pada Allah. Sementara peristiwa suka mengingatkan orang percaya untuk selalu bersyukur atas kemurahan Allah. Tubuh adalah bait Allah, tempat Allah bersemayam yang berarti bahwa segala laku orang percaya harus memanifestasikan sifat-sifat Allah di tengah-tengah dunia ini. Allah adalah pemberi hidup dan Dia jugalah sebagai pemiliknya. Oleh karena itu tubuh tidak boleh dimatikan oleh siapapun kecuali oleh kehendak Allah. Oleh karena itu jikalau seseorang telah melakukan tindakan bunuh diri maka dia telah menyangkali kedaulatan Allah sebagai pemberi dan pemilik hidup. Orang yang melakukan tindakan bunuh diri berarti menolak hidup.

Oleh karena itu, beberapa hal yang menjadi kesimpulan dari penelitian ini adalah: 
1. Tindakan bunuh diri adalah merupakan tindakan sadar dan sengaja untuk mematikan diri sendiri yang dipahamai sebagai jalan untuk menghindari penderitaan.

2. Keterpisahan hidup dengan tubuh Kristus menjadi faktor utama seseorang secara tersu menerus diperbudak oleh dosa, hingga terjadi tindakkan bunuh diri pada orang-orang tertentu (band. 2 Kor. 5:17). Karena keberadaannya diluar Kristus, maka ketika masalah datang ukuran-ukuran kebaikan atas persoalan untuk mengambil keputusan adalah dirinya sendiri bukan otoritas Kristus. Ego manusia batiniah pelaku bunuh diri yang terus yakin dan berjuang pada ukuran hukum dan perbuatan-perbuatannya yang dianggapnya dapat meraih sorga, hal itulah yang merusak seuluruh tatanan kehidupannya hingga pada kematiaanya.

3. Predestinasi dan provinedensia Allah terjadi supaya setiap orang diselamatkan dan keselamatan itu bertujuan untuk memuliakan Allah melalui seluruh eksistensi manusia baik di bumi maupun di sorga, itulah kedaulatan Allah (band. Rom.11:36). Sehingga sekalipun masih memungkinkan bagi orang pilihan Allah untuk melakukan dosa di dunia ini, namun karena kedaulatan Allah tidak mungkin tidak memberikan ruang untuk menyesali dan mengakui dosanya. Kesempatan pengakuan itu pasti diberi (tujuannya bukan supaya diselamatkan kembali, melainkan peristiwa itu menjadi penyataan kasih Allah pada setiap orang percaya dan juga pada dunia). Tanda inilah yang tidak dimiliki orang yang melakukan dosa bunuh diri (band. Maz. 37:23-23, 1 Yoh. 1:5-10).

\section{Referensi}

Donna, Sylva. Keselamatan dari Orang Kristen yang Bunuh Diri, 2013.

Febi, Josephine Gracia. "Josephine Gracia Febi, Bunuh Diri Ditinjau Dari Iman Kristen". https://tobiong.wordpress.com/2009/08/08/21/\#_ftn65.

Herman Bavinck. Dogmatika Reformed, Jilid 3, Terjemahan Ichwe G. Indra dan Irwan Tjulianto. Surabaya: Momentum, 2016.

Louis Berkhof. Teologi Sistematika; Doktrin Akhir Zaman, Terjemahan Yudha Thianto. Surabaya: Momentum, 2008.

Mallo, Hermin, and Daniel Ronda. "Analisis Faktor Penyebab Utama Kecenderungan Bunuh Diri di Kalangan Remaja yang Berusia 15-17 Tahun di Makassar". Analisis Faktor Penyebab Utama Kecenderungan Bunuh Diri di Kalangan Remaja yang Berusia 15-17 Tahun di Makassar 8.1, no. Jurnal Jaffray (2010): 35-43.

Milliard J. Erickson. Teologi Kristen, (Vol. 3),. Malang: Gandum Mas, 2004. 


\section{JURNAL LUXNOS}

Volume 7 Nomor 1, Juni 2021

Parker, J.J. Penginjilan dan Kedaulatan Allah. Surabaya: Momentum, 2003.

R. C. Sproul. Kaum Pilihan Allah, (Terjemahan Rahmiati Tanudjaja). Malang: Literatur SAAT, 1995.

Ridderbos, Herman. Paulus: Pemikiran Utama Theologinya, Terjemahan Hengky Ongkowidjojo. Surabaya: Momentum, 2008.

Santoso, Meilanny Budiarti, Dessy Hasanah Siti Asiah, and Chenia Ilma Kirana. "Bunuh Diri Dan Depresi Dalam Perspektif Pekerjaan Sosial". Penelitian Dan Pengabdian Kepada Masyarakat 4.3 (2018): 390-398.

Santoso, Dkk. Bunuh Diri Dan Depresi Dalam Perspektif Pekerjaan Sosial. Prosiding Penelitian Dan Pengabdian Kepada Masyarakat 4.3, 2018.

Yohannes Calvin. Institutio, Terjemahan Winarsih dan J.S. Aritonang. Jakarta: BPK Gunung Mulia, 2009.

"http://eprints.mercubuana-yogya.ac.id/942/3/5.\%20BAB\%20II.pdf http://etheses.uinmalang.ac.id/806/6/10410163\%20Bab\%202.pdf. http://repository.usu.ac.id/bitstream/handle/123456789/18244/Chapter\%20II.p df;jsessionid=823E174616E5C72CE87ED375D46FEB9D?sequence=4".

"https://www.intothelightid.org/tentang-bunuh-diri/apa-itu-bunuh-diri-yang-orangsering-tanyakan-tentang-bunuh-diri/".

"Kamus Besar Bahasa Indonesia (KBBI), Versi Online". https://kbbi.web.id/bunuh. 